\section{Federico Ceresoli}

PhD student

University of Brescia

Department of Mechanical and Industrial

Engineering

\section{Excavator with Two or Three Arms: Dynamical Behavior and Structural Implications}

The purpose of this work is to compare, with the same digging diagrams, the velocity, accelerations and dynamic performances of two excavators with different arm configurations. In particular, constructive solutions involving the use of two and three mobile arms will be examined. For excavators the different construction geometry (2-3 arms) is mainly dictated by reasons of use, in fact the 3 arms solution is normally used in areas that allow poor mobility of vehicle and present obstacles during the excavation phase. The dynamic comparison between the two solutions is performed on real working conditions to which they can be subjected during the exercise. The elaborations are performed both analytically and numerically. Essentially the analysis shows that in the condition of leveling and lifting at minimum distance from the rotation axis the dynamic performances are similar, there are significant differences in the lifting condition at the maximum distance. The diversity also implies significant variations in the forces of the hydraulic cylinders used to move both the load and the arms, an aspect which finds greater emphasis even in the case in which the arms are made by adopting unconventional materials for their realization as aluminum and composites.

Keywords : excavator, load conditions, forward kinematics, inverse kinematics, dynamic actions, lightweight.

\section{INTRODUCTION}

Excavators are very versatile earth-moving machines, they have a wide payload range (from $5000 \mathrm{~kg}$ to 50000 $\mathrm{kg}$ ) which obviously also corresponds to a different load diagram (for example digging depth from $3 \mathrm{~m}$ to $12 \mathrm{~m}$ and distance from the rotation axis from $4 \mathrm{~m}$ to $15 \mathrm{~m}$ ) [1]. In general these machines can be differentiated by the number of arms. With equal fundamental components such as the frame, cab, engine (mainly endothermic), hydraulic system, etc., there are two types of excavators: the first with two arms and the second with three arms (Figure 1). The choice between the two possible configurations is carried out by the costumer in relation to personal experience than to objective evaluations. This work fits into this perspective and the main goal is an objective evaluation of the performance of the same type of excavator (medium-large excavator) with two and three arms. Since the working conditions are different, three specific working situations have been chosen, considering these as the most usual and significant methods of use of an excavator, they are: leveling, lifting at the minimum and maximum distance from the rotation axis. Through different approach (analytical and numerical) the dynamic performances of the arms have

Recevied: December 2019, Accepted: February 2020

Correspondence to: Eng. Federico Ceresoli

Departement of Mechanical and Industrial Enineering, University of Brescia Via Branze, 38, Brescia, Italy

E-mail: f.ceresoli002@unibs.it

doi:10.5937/fme2002272C

(C) Faculty of Mechanical Engineering, Belgrade. All rights reserved been studied, comparing the results in graphic form and summarizing the same in tabular form. The last part of the work concerns the implications of the results obtained on the forces generated by the hydraulic cylinders (suitable for moving the arms) also considering the possibility of a structural lightweighting of the arms.

\section{DESCRIPTION OF THE MACHINES}

The vehicle chosen to perform this comparative study is the excavator PC 210 of the Komatsu company. The choice of this machine was made because the excavator in question is widely used in the field of material handling and in the ordinary maintenance of roads and waterways. Another fundamental aspect for the choice was the fact that it had available for experimental test and also to have some technical information available. A further point in favor of this machinery is the possibility of being able to choose the configuration with two or three arms, taking as a basis the complete engine/cabin and track unit, practically modifying only the geometrical configuration of the arms (Figure 1).

Table 1. Main dimensions for two and three arms excavator

\begin{tabular}{|l|c|c|}
\hline PC $210[\mathrm{~mm}]$ & 2 arms & 3 arms \\
\hline A & 2500 & 2500 \\
\hline B & 3035 & 3035 \\
\hline C & 3000 & 3000 \\
\hline D & 3190 & 3090 \\
\hline E & 9555 & 9420 \\
\hline F & 5700 & 5970 \\
\hline G & 4080 & 4080 \\
\hline
\end{tabular}

FME Transactions (2020) 48, 272-280 272 

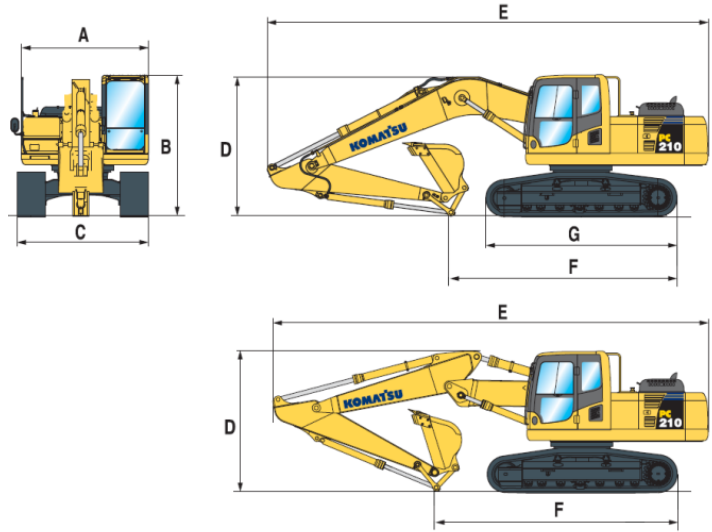

Figure 1. PC 210 two and three arms configuration

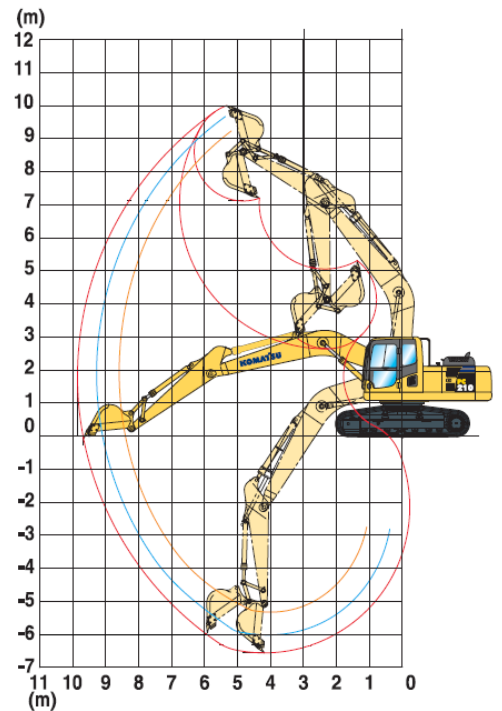

Figure 2. Digging diagram for two arms configuration

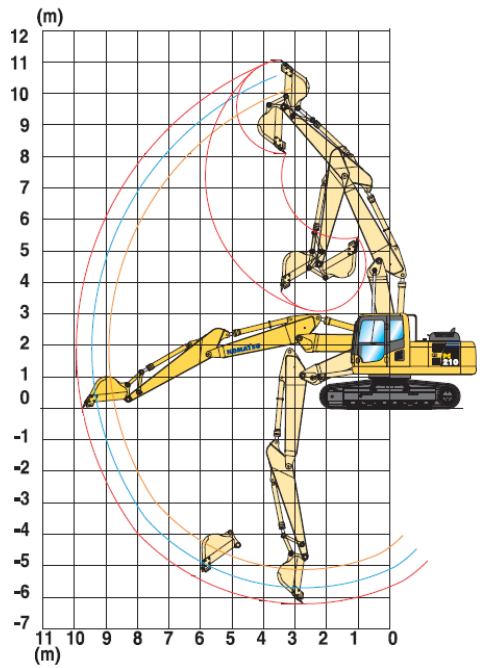

Figure 3. Digging diagram for three arms configuration

The digging diagrams of the machine are shown in the two different configurations (Figure 2, Figure 3). As can be seen, there is not a noticeable difference in the excavation diagrams as in the dimensions shown in Table1. The choice of a double or triple articulated excavator can be dictated by the fact that the work may require more flexibility in reaching a certain point. In fact, although the two configurations guarantee almost the same work area [2] (Figure 2, Figure 3), the exca- vator in triple articulation configuration, presenting an additional degree of freedom, allows to reach the same point of a double articulated excavator, but with greater flexibility, managing to overcome any obstacles present on the course or in the excavation area.

\subsection{Load conditions}

In order to compare the possible movements of the two solutions, three load conditions have been imposed which can be seen as the basic movements during a work cycle.

The load conditions chosen are the following: -Load condition 1 (leveling): in this phase the arms are completely extended with the bucket resting on the ground, the movement consist in the bucket approaching the body of the excavator;

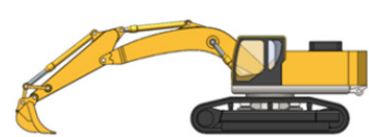

(a)

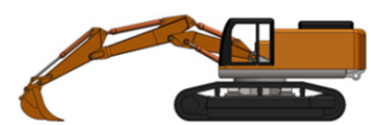

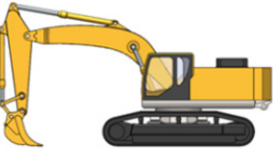

(b)
Figure 4. Load condition 1: (a) start, (b) end

-Load condition 2 (lifting at the minimum distance): during this phase the arms are arranged so as to be able to carry out a lifting action with the bucket positioned as close as possible to the body of the vehicle under examination;

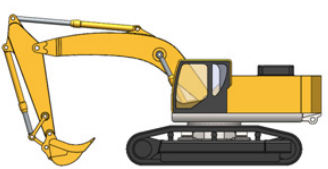

(a)

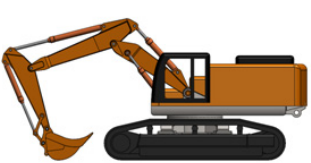

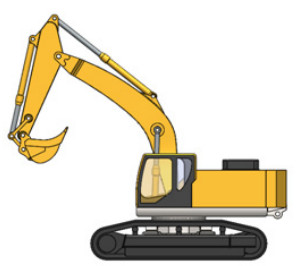

(b)

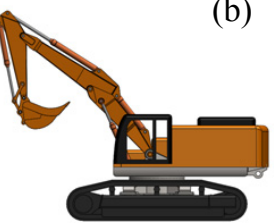

Figure 5. Load condition 2: (a) start, (b) end

-Load condition 3 (lifting at the maximum distance): with this configuration the machine appears as in the leveling condition, with the only difference that in this case the arms will not have the carry out a leveling action, but a lifting action and therefore the bucket will have to perform a movement in a vertical direction and not a horizontal one.

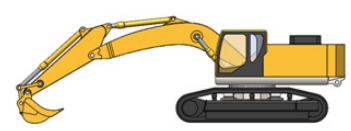

(a)

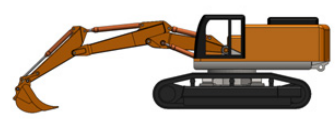

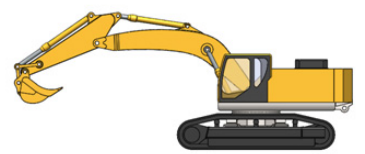

(b)

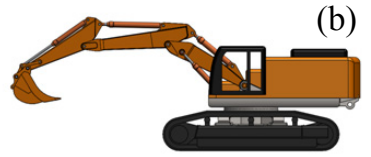

Figure 6. Load condition 3: (a) start, (b) end 


\subsection{Background theory for excavator with 2 arms}

In order to be able to compare the results of the arm movements and so be able to estimate the accelerations and velocities present during the performance of the three different loading conditions previously described, it was decided to impose on the attachment area of the bucket of both constructive solutions, the same law of motion. We will then proceed to the study of the cases under examination through two different approaches: one analytical, and one by simulation through the use of software dedicated to the study of movements.

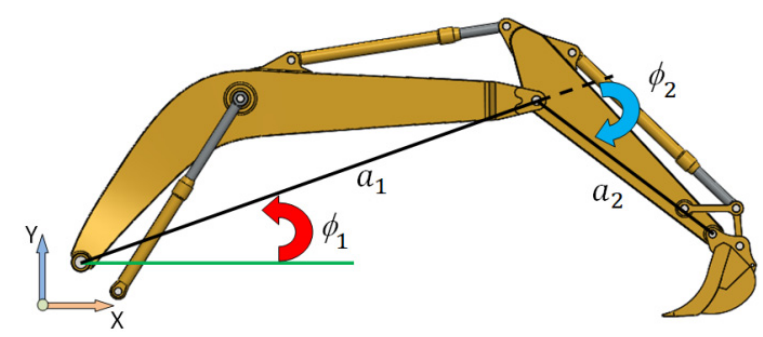

Figure 7. Two arms schematization

To be able to define the position of the bucket, for the two and three arm configuration we used the Denavit-Hartemberg convention[3,4], which provides to define the position and orientation of the consecutive arms (1) and (2).

Position of the ends of the arms:

$H_{\text {boom }}=\left[\begin{array}{cccc}\cos \left(\Phi_{2}\right) & -\sin \left(\Phi_{2}\right) & 0 & a_{1} \cos \left(\Phi_{2}\right) \\ \sin \left(\Phi_{2}\right) & \cos \left(\Phi_{2}\right) & 0 & a_{1} \sin \left(\Phi_{2}\right) \\ 0 & 0 & 1 & 0 \\ 0 & 0 & 0 & 1\end{array}\right]$
$H_{\text {boom }}=\left[\begin{array}{cccc}\cos \left(\Phi_{2}\right) & -\sin \left(\Phi_{2}\right) & 0 & a_{1} \cos \left(\Phi_{2}\right) \\ \sin \left(\Phi_{2}\right) & \cos \left(\Phi_{2}\right) & 0 & a_{1} \sin \left(\Phi_{2}\right) \\ 0 & 0 & 1 & 0 \\ 0 & 0 & 0 & 1\end{array}\right]$

Bucket end position

$$
H=H_{\text {boom }} \cdot H_{\text {stick }}
$$

Known the matrix H (3) it is now possible to obtain the components of the position in $\mathrm{x}$ and $\mathrm{y}$ of the end of the stick as reported by equations (4) and (5).

$$
\begin{aligned}
& x=a_{1} \cos \left(\Phi_{1}\right)+a_{2} \cos \left(\Phi_{1}+\Phi_{2}\right) \\
& y=a_{1} \sin \left(\Phi_{1}\right)+a_{2} \sin \left(\Phi_{1}+\Phi_{2}\right)
\end{aligned}
$$

\subsection{Background theory for excavator with 3 arms}

The same procedure can be repeated for the three arms configuration. So obtaining the positions (6), (7) and (8) of the arms and the position of the end of the stick in $\mathrm{x}$ (10) and y (11).

$$
H_{1}=\left[\begin{array}{cccc}
\cos \left(\vartheta_{1}\right) & -\sin \left(\vartheta_{1}\right) & 0 & a_{1} \cos \left(\vartheta_{1}\right) \\
\sin \left(\vartheta_{1}\right) & \cos \left(\vartheta_{1}\right) & 0 & a_{1} \sin \left(\vartheta_{1}\right) \\
0 & 0 & 1 & 0 \\
0 & 0 & 0 & 1
\end{array}\right]
$$

$$
\begin{aligned}
& H_{2}=\left[\begin{array}{cccc}
\cos \left(\vartheta_{2}\right) & -\sin \left(\vartheta_{2}\right) & 0 & a_{1} \cos \left(\vartheta_{2}\right) \\
\sin \left(\vartheta_{2}\right) & \cos \left(\vartheta_{2}\right) & 0 & a_{1} \sin \left(\vartheta_{2}\right) \\
0 & 0 & 1 & 0 \\
0 & 0 & 0 & 1
\end{array}\right] \\
& H_{3}=\left[\begin{array}{cccc}
\cos \left(\vartheta_{3}\right) & -\sin \left(\vartheta_{3}\right) & 0 & a_{1} \cos \left(\vartheta_{3}\right) \\
\sin \left(\vartheta_{3}\right) & \cos \left(\vartheta_{3}\right) & 0 & a_{1} \sin \left(\vartheta_{3}\right) \\
0 & 0 & 1 & 0 \\
0 & 0 & 0 & 1
\end{array}\right] \\
& x=a_{1} \cos \left(\vartheta_{1}\right)+a_{2} \cos \left(\vartheta_{1}+\vartheta_{2}\right)+a_{3} \cos \left(\vartheta_{3}+\vartheta_{3}\right)
\end{aligned}
$$

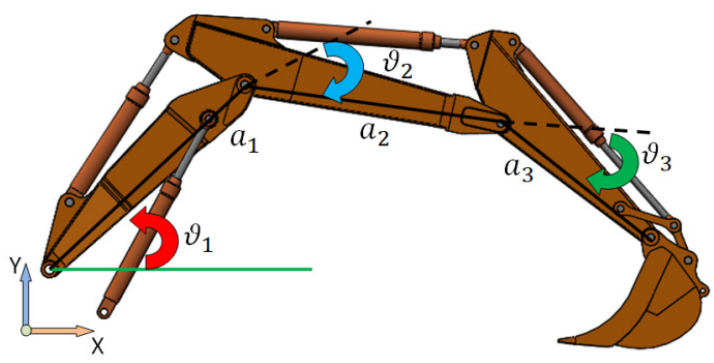

Figure 8. Three arms schematization

\section{PARAMETERS FOR THE MOVEMENT SIMULATION}

To conduct the comparison it will be necessary to use the same parameters [5] related to both the laws of motion of the three different load conditions and the characteristics of the moving elements [6,7] (length, duration of the movement in terms of time and space) $[8,9]$. In order to conduct a simulation in a 3D work environment it is necessary to create the solid models of the elements $[10,11]$ that we want to analyze [12-14], for this reason arms of both excavator solutions, two and three arms, have been created. As can be seen from Figure 9, the representation of excavators has been considerably simplified, in fact for both solutions the frame and the arms have been reported alone going to leave out components such as the hydraulic cylinders or the bucket. This choice was made both to simplify as much as possible the model, so to lighten the simulation, but also because in this way it is possible to bring back the geometry of the arms of an excavator to the geometry of a SCARA robot taken as a base of study for this comparative work $[15,16]$. To proceed with the simulation $[17,18]$, once the components have been made and the necessary constraints and couplings have been set, it was decided to place a "motor" at the end of the stick, in correspondence of the fixing pin between the bucket and the stick going to set the law of motion.

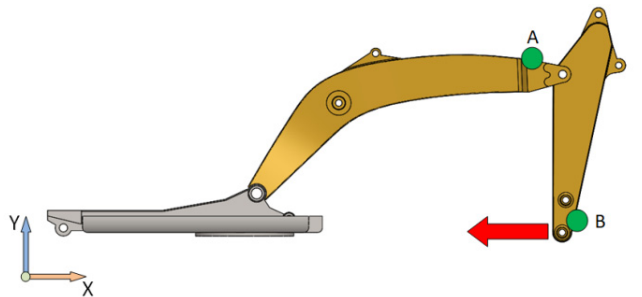

Figure 9. Motor position (red arrow) 
In this way the movement of the arms is induced by the movement and the position of the point where the motor is applied.

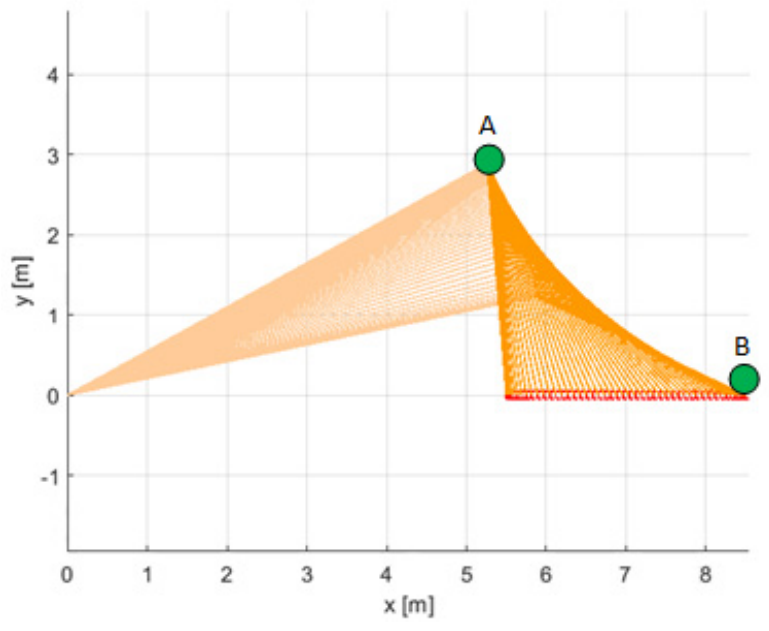

Figure 10. Diagram of the leveling movement for the two arms excavator

In order to determine the parameters of the law of motion such as: the distance covered by the bucket and the times, we proceeded with an experimental test of the movement going to take the total run of the movement and the time needed to complete it. In accordance with the experimental test, some of which are present in [19], and with the characteristics of the present hydraulic system (maximum flow rate $450 \mathrm{l} / \mathrm{min}$ ) it was possible to estimate the velocity of motion of the cylinders and therefore the parameters of the laws of motion of the arms.

Parameters of the law of motion (Figure 10): - total travel: $7000 \mathrm{~mm}$

The velocity and the acceleration were obtained algebraically having assumed a transient time, in which the element accelerates, equal to $0.33 \mathrm{~s}$ and considering that the element performs a movement of $7000 \mathrm{~mm}$ in $4 \mathrm{~s}$.

$$
\begin{aligned}
& \Delta S_{\text {tot }}=\Delta S_{1}+\Delta S_{2}+\Delta S_{3}=\frac{1}{2} a t_{1}^{2}+\left(a t_{1} t_{2}\right)+ \\
& +\left(a t_{1} t_{3}-\frac{1}{2} a t_{3}^{2}\right)
\end{aligned}
$$

where:

$\mathrm{a}=$ acceleration

$\mathrm{t}_{1}=$ acceleration time

$\mathrm{t}_{2}=$ time with constant acceleration

$\mathrm{t}_{3}=$ deceleration time

with $\mathrm{t}_{1}=\mathrm{t}_{3}$

Obtaining:

- maximum acceleration: $1432 \mathrm{~mm} / \mathrm{s}^{2}$

- maximum velocity: $477 \mathrm{~mm} / \mathrm{s}$

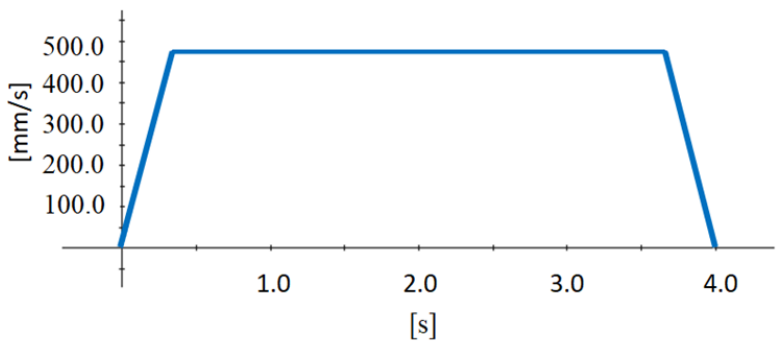

\section{COMPARISON BETWEEN 2 AND 3 ARMS SOLUTION}

Comparison of the simulations of the leveling condition between MeCad, free software developed by the University of Brescia for the modeling of articulated systems and cams [20] and Soliworks software.

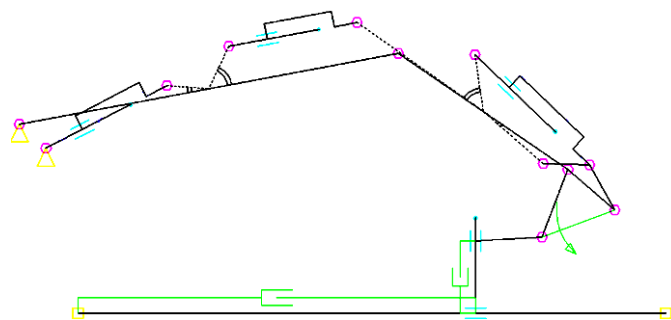

Figure 12. Model for simulation in MeCad software

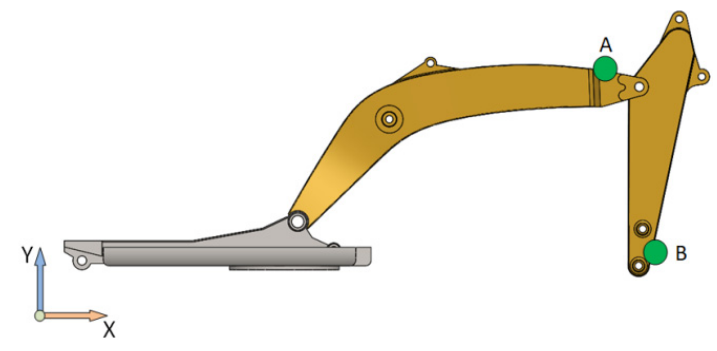

Figure 13. Position of the survey points (A and B) for two arms excavator
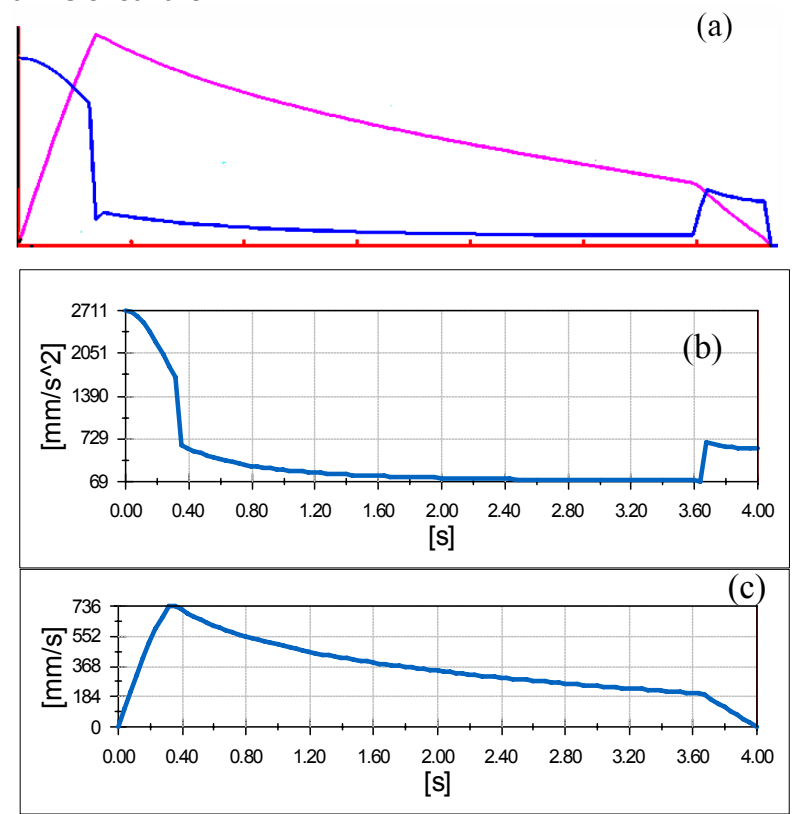

Figure 14. (a) acceleration and velocity MeCad, (b) acceleration SolidWorks, (c) velocity SolidWorks for the point A

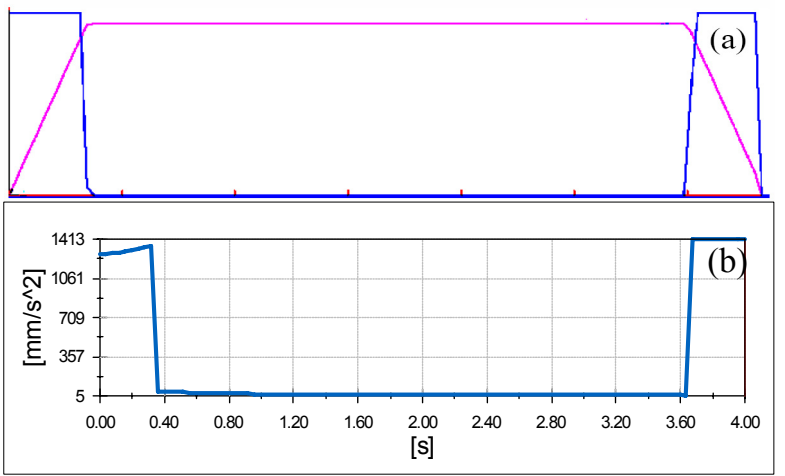

Figure 11. Law of motion 


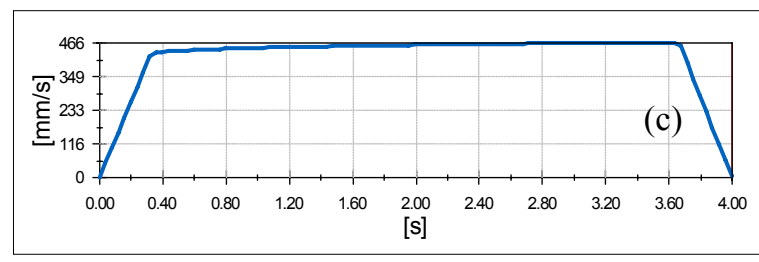

Figure 15. (a)acceleration and velocity MeCad, (b) acceleration SolidWorks, (c) velocity SolidWorks for the point B

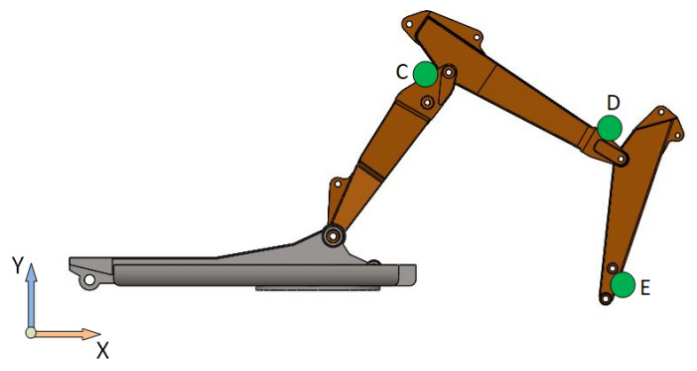

Figure 16. Position of the survey points (C,D and E) for three arms excavator

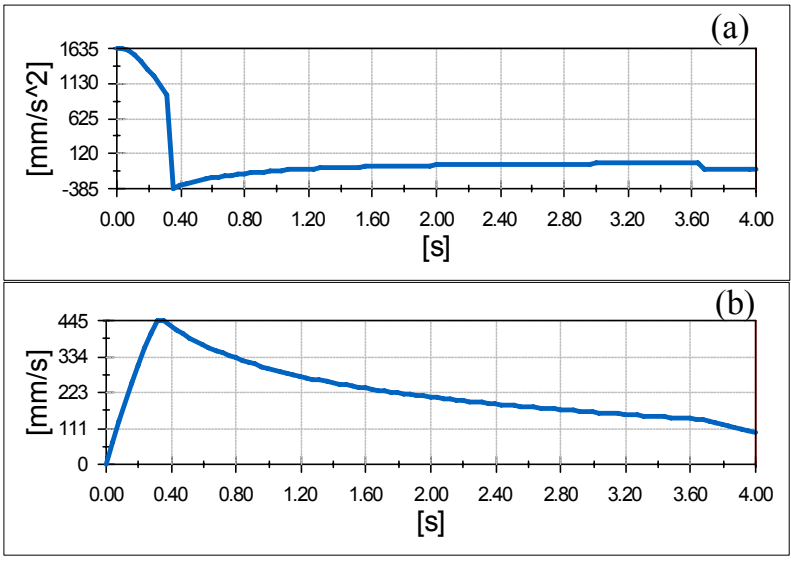

Figure 17. Acceleration (a) and velocity (b) simulation in point $\mathrm{C}$
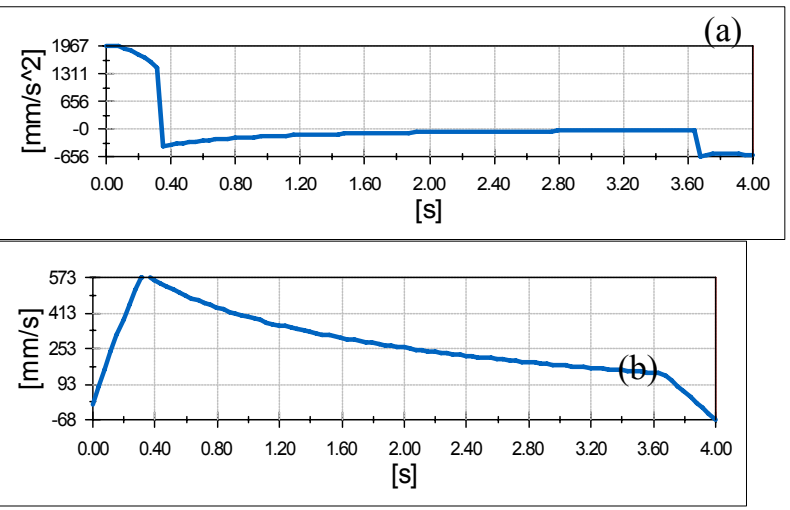

Figure 18. Acceleration (a) and velocity (b) simulation in point $D$

As you can see from the graphs of Figures 14adnd 15 , the values obtained through the implementation with MeCad and Solidworks software provide coincidents andaments of velocities and accelerations.

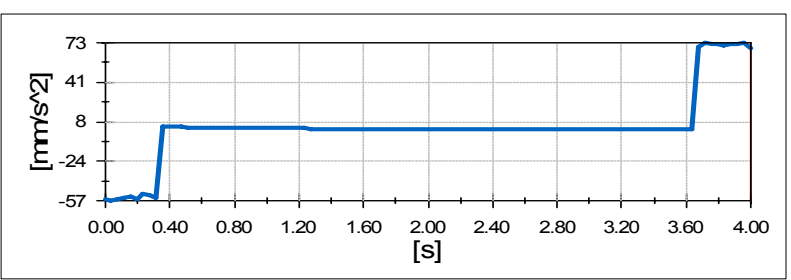

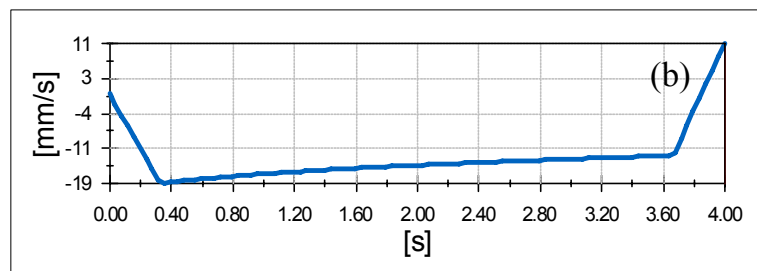

Figure 19. Acceleration (a) and velocity (b) simulation in point $E$

\section{-BARICENTERS, ANGULAR AND LINEAR ACCE-} LERATION MODULE

Once compared and given the reliability of the results obtained, we have moved on to simulate using Solidworks, but this time considering as the acceleration point, not the position previously reported, but the center of gravity of each arm, so to estimate the behavior of the arms through the principle of D'Alembert and to obtain the trends Figure 21-22 Figure 24-31 and obtain the maximum and minimum linear and angular accelerations Table 2-3-4.

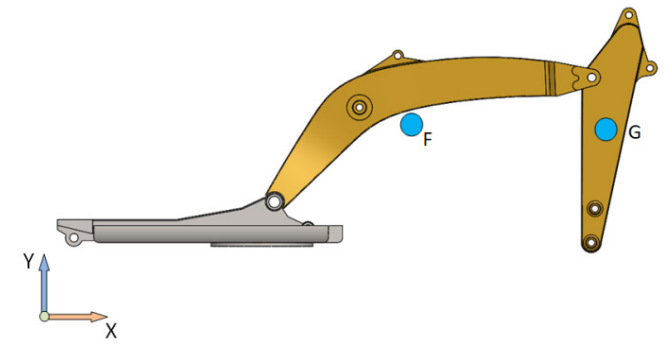

Figure 20. Position of the barycentric points ( $F$ and $G$ ) for two arms excavator

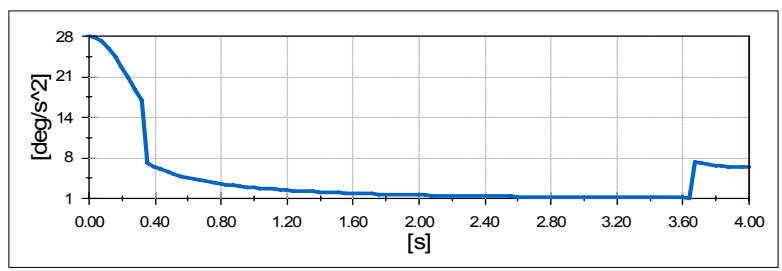

Figure 21. Trend of angular acceleration module point $F$

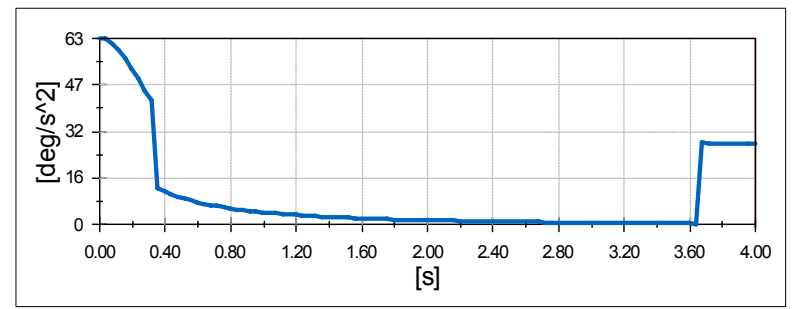

Figure 22. Trend of angular acceleration module point $\mathrm{G}$

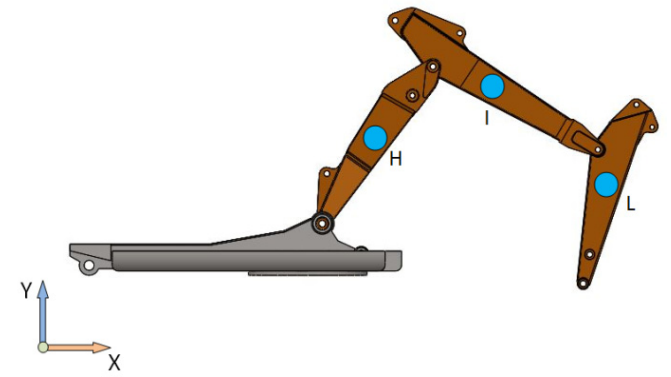

Figure 23. Position of the barycentric points $(H, I$ and $L)$ for three arms excavator 


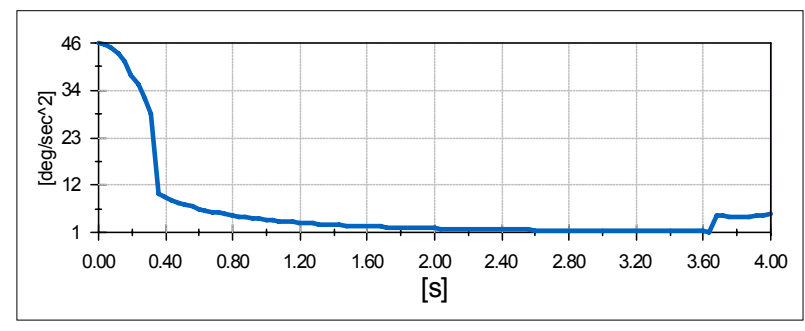

Figure 24. Trend of angular acceleration module point $\mathbf{H}$

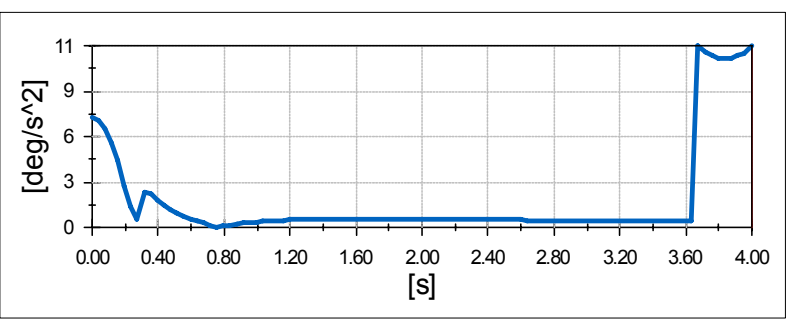

Figure 25. Trend of angular acceleration module point I

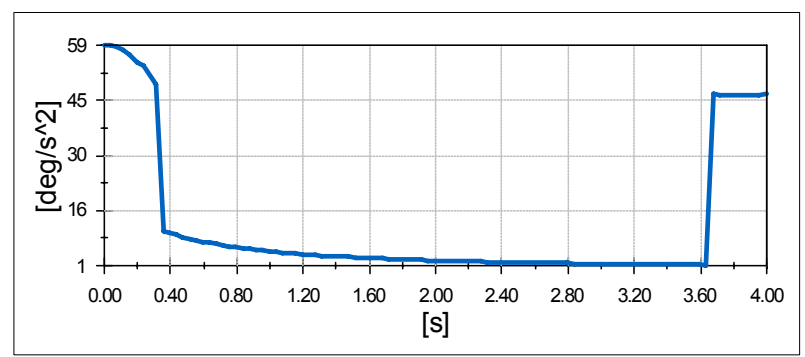

Figure 26. Trend of angular acceleration module point $\mathbf{L}$

Graphs of linear acceleration module

-2 arms

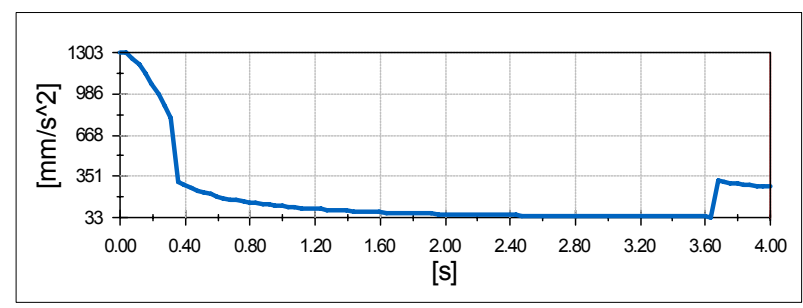

Figure 27. Trend of linear acceleration module point $F$

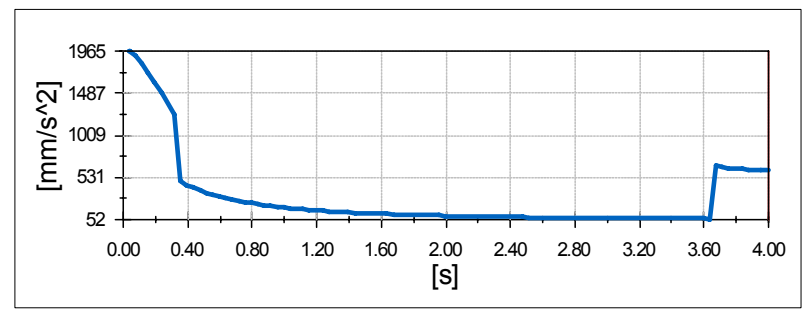

Figure 28. Trend of linear acceleration module point $G$

-3 arms

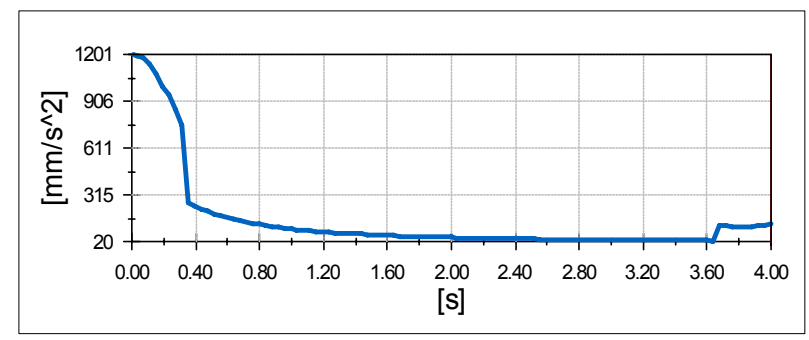

Figure 29. Trend of linear acceleration module point $\mathbf{H}$

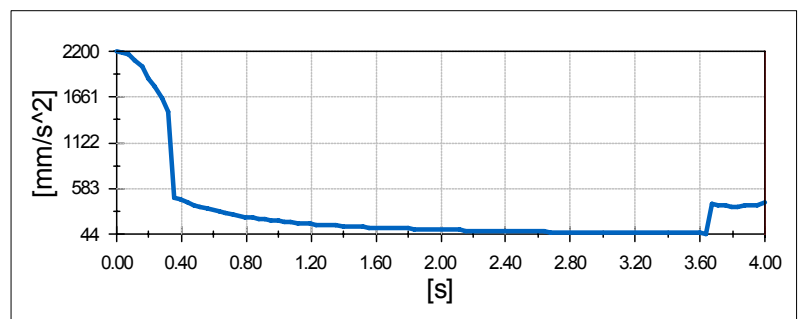

Figure 30. Trend of linear acceleration module point I

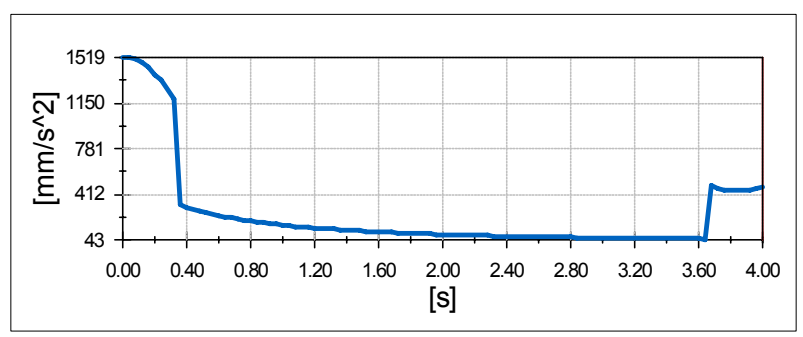

Figure 31. Trend of linear acceleration module point $L$

\section{CONSIDERATIONS}

The two geometric solutions have the same overall dimensions, the same excavation diagram and more or less the same load capacity, moreover the overall weight of the excavator, passing from the two to the three arms solution, substantially does not vary; the slight increase in weight present in the triple articulation solution is due to the presence of an additional hydraulic cylinder. Below are reported the results for linear and angular accelerations, maximum and minimum values, for the three different loading conditions. Table 2 shows the accelerations of the center of gravity of the arms for the two configurations ( 2 and 3 arms) related to the load condition 1 (leveling) in which we considered as the law of motion the one shown in Figure 11. Regarding the accelerations for the load condition 2 (lifting at minimum distance) and the load condition 3 (lifting at maximum distance) the results, of the accelerations of the center of gravity, are reported respectively in Table 3 and in Table 4, for these two load conditions a constant lifting speed of $500 \mathrm{~mm} / \mathrm{s}$ has been set.

Table 2. Maximum and minimum linear and angular acceleration values for load condition 1 - leveling

\begin{tabular}{|c|c|c|c|c|c|}
\hline & & $\begin{array}{c}\mathrm{a}_{\max } \\
{\left[\mathrm{mm} / \mathrm{s}^{2}\right]}\end{array}$ & $\begin{array}{c}\mathrm{a}_{\min } \\
{\left[\mathrm{mm} / \mathrm{s}^{2}\right]}\end{array}$ & $\begin{array}{c}\dot{\omega}_{\max } \\
{\left[\% \mathrm{~s}^{2}\right]}\end{array}$ & $\begin{array}{c}\dot{\omega}_{\min } \\
{\left[\% \mathrm{~s}^{2}\right]}\end{array}$ \\
\hline \multirow{2}{*}{2 ARMS } & $\mathrm{F}$ & 1303 & 33 & 26 & 1 \\
\cline { 2 - 6 } & $\mathrm{G}$ & 1965 & 52 & 63 & 0 \\
\hline \multirow{3}{*}{3 ARMS } & $\mathrm{H}$ & 1201 & 20 & 46 & 1 \\
\cline { 2 - 6 } & $\mathrm{I}$ & 2200 & 44 & 11 & 0 \\
\cline { 2 - 6 } & $\mathrm{L}$ & 1519 & 43 & 59 & 1 \\
\hline
\end{tabular}

Table 3. Maximum and minimum linear and angular acceleration values for load condition 2 - lifting at the minimum distance

\begin{tabular}{|c|c|c|c|c|c|}
\hline & & $\begin{array}{c}\mathrm{a}_{\max } \\
{\left[\mathrm{mm} / \mathrm{s}^{2}\right]}\end{array}$ & $\begin{array}{c}\mathrm{a}_{\min } \\
{\left[\mathrm{mm} / \mathrm{s}^{2}\right]}\end{array}$ & $\begin{array}{c}\dot{\omega}_{\max } \\
{\left[\% \mathrm{~s}^{2}\right]}\end{array}$ & $\begin{array}{c}\dot{\omega}_{\min } \\
{\left[\% \mathrm{~s}^{2}\right]}\end{array}$ \\
\hline \multirow{2}{*}{2 arms } & $\mathrm{F}$ & 22.7 & 21 & 0.11 & 0 \\
\cline { 2 - 6 } & $\mathrm{G}$ & 51 & 47 & 0.11 & 0 \\
\hline \multirow{3}{*}{$3 \mathrm{arms}$} & $\mathrm{H}$ & 33 & 19 & 1.3 & 0.7 \\
\cline { 2 - 6 } & $\mathrm{I}$ & 31 & 16 & 2.2 & 0 \\
\cline { 2 - 6 } & $\mathrm{L}$ & 90 & 40 & 3.2 & 1.4 \\
\hline
\end{tabular}


Table 4. Maximum and minimum linear and angular acceleration values for load condition 3 - lifting at the maximum distance

\begin{tabular}{|c|c|c|c|c|c|}
\hline & & $\begin{array}{c}\mathrm{a}_{\max } \\
{\left[\mathrm{mm} / \mathrm{s}^{2}\right]}\end{array}$ & $\begin{array}{c}\mathrm{a}_{\min } \\
{\left[\mathrm{mm} / \mathrm{s}^{2}\right]}\end{array}$ & $\begin{array}{c}\dot{\omega}_{\max } \\
{\left[\% / \mathrm{s}^{2}\right]}\end{array}$ & $\begin{array}{c}\dot{\omega}_{\min } \\
{\left[\% / \mathrm{s}^{2}\right]}\end{array}$ \\
\hline \multirow{2}{*}{2 arms } & $\mathrm{F}$ & 9.07 & 8.96 & 0.02 & 0 \\
\cline { 2 - 6 } & $\mathrm{G}$ & 23.55 & 23.26 & 0.02 & 0 \\
\hline \multirow{3}{*}{3 arms } & $\mathrm{H}$ & 101 & 35 & 3.7 & 1.3 \\
\cline { 2 - 6 } & $\mathrm{I}$ & 168 & 35 & 2.5 & 1.6 \\
\cline { 2 - 6 } & $\mathrm{L}$ & 92 & 34 & 3.2 & 0 \\
\hline
\end{tabular}

\section{RESULTS AND IMPLICATIONS}

On the basis of the results reported in Tables 2-4 and on the basis of the work concerning the lightweighting [2123] of the arms of an excavator using aluminum and composite materials [19-24] and also of other components [25], an evaluation of the actions that the hydraulic cylinders must generate to move the load and the arms was made [26].

In particular, Figure 32 shows, as an example, the distribution of the Von Mises stresses present in the arms of the excavator of the two geometric configurations defined in the present work or with two and three arms, at the start of the loading condition 3 which constitutes the most critical condition for the structure.

Table 5. Variation of forces according to the construction material

\begin{tabular}{|l|c|c|c|c|c|}
\hline$[\mathrm{kN}]$ & Steel & Aluminum & red.\% & Composite & red.\% \\
\hline F1 & 471.2 & 382.0 & 19 & 325.7 & 31 \\
\hline F2 & 238.8 & 216.1 & 10 & 201.8 & 15 \\
\hline F3 & 135.7 & - & - & - & - \\
\hline F4 & 754.0 & 432.6 & 43 & 367.5 & 51 \\
\hline F5 & 659.7 & 553.2 & 16 & 486.1 & 26 \\
\hline F6 & 596.9 & 547.8 & 8 & 507.9 & 15 \\
\hline F7 & 261.1 & - & - & - & - \\
\hline
\end{tabular}
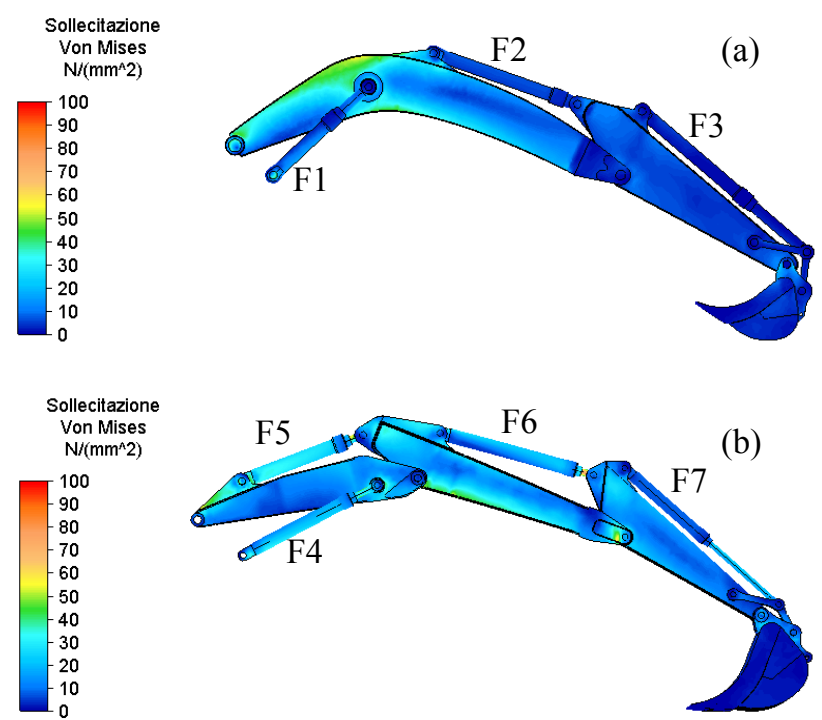

Figure 32. Stresses present in the two (a) and three (b) arms configuration

Table 5 shows the values of the maximum forces that the cylinders must exercise to balance the load handled, the weight of the arms and the weight of the accessories. The table shows a considerable reduction in the forces exerted by the hydraulic cylinders, also considering the variability of the material hypothesized for the realization of the arms and the actuators. The value of the forces exerted by the hydraulic cylinders F3 and F7 is unchanged since it depends on the bucket and not on the structural optimization of the arms. The range varies from $8 \%$ to $50 \%$ thus made possible a significant reduction in the maximum forces. It is important to underline that also hydraulic cylinders can be object of weight optimization [27-28], thus reduce their incidence on the overall weight of the arms.

\section{CONCLUSION}

The present research concerns the kinematic and dynamic analysis of a two and three excavator arms comparing their behavior on real load conditions evaluated experimentally. The comparison was performed analytically and numerically with two software obtaining a substantial convergence in the values and in the acceleration trends for the different points that identify the arms. These values were used to optimize the weight of the arms of the excavators, focusing also on the hydraulic cylinders needed to move the load and the arms. From the results it emerges that the two configurations (two or three arms) have a similar dynamic behavior, only the lifting condition at maximum distance shows significant divergences. The weight optimization by adopting different materials for the realization of arms such as aluminum or composite materials instead of the classical construction steel, considering the different load conditions analyzed and considering the dynamic effects, leads to a significant reduction of forces exercised by the hydraulic cylinders to move the arms and the load. The research is being developed especially for what concern the study of an excavator in which not only the arms, but also the cylinders (and in general the whole structure of the machine) are made with unconventional materials. At the same time, the research is carried out on the performance about the dynamic behavior of the vehicle, in particular its stability in relation to the load handled and to the material used for the construction of the whole machine, all in function of the ground, specifically the overcoming slope.

\section{REFERENCES}

[1] Herbert, L., Nichols, Jr., David Day: Moving the Earth: The Workbook of Excavations Sixth Edition, McGraw-Hill Education ISBN-13: 9780-007150 2672, ISBN-10: 007150267X, 2010.

[2] Kudryavtsev, E.M.: Computer Modelling of a Digging Zone of a Single-bucket Excavator, IMK-14Research\&Development in Heavy Machinery, Vol. 23, No. 3, 2017.

[3] Petrovic, P.B., Lukic, N.A.: Configuration-based Compliance Control of Kinematically Redundant Robot Arm Part I - Theoretical Framework, FME Transactions, Vol. 45, No. 4 pp. 468-474, 2017.

[4] Petrovic, P.B. and Lukic, N.A.: Configurationbased Compliance Control of Kinematically Redundant Robot Arm Part II - Experimental 
Validation, FME Transactions, Vol. 45, No. 4 pp. 475-480, 2017.

[5] Janosevic, D., Milic, P., Markovic, D. and Nikolic, V.: Optimization of Kinematic Chain Parameters in Hydraulic Excavators, IMK-14-Research \& Development, Vol. 18, No.2, 2012.

[6] Koivo, A.J.: Kinematics of excavators (backhoes) for transferring surface material, Journal of aerospace engineering, Volume 7 No. 1 pp. 17-32, 1994.

[7] Koivo, A.J., Thoma, M., Kocaoglan, E. AndradeCetto J.: Modeling and Control of Excavator Dynamics during Digging Operation, Journal of aerospace engineering, Volume 9, No. 1 pp. 10-18, 1996.

[8] Cao, Y., Xie, Y.: Dynamic modeling of the front structure of an excavator, Non linear Dynamic, Vol. 91, pp. 233-247, 2018.

[9] Rupar, D., Hladnik, J., Jerman, B.: Loader Crane Inertial forces, FME Transactions, Vol. 44, No. 3 pp. 291-297, 2016.

[10] Bosnjak, S., Zrnic, N. and Oguamanam, D.: On the dynamic modeling of bucket wheel excavators, FME Transactions, Vol. 34, No. 4, pp.221-226, 2006.

[11] Gnjatovic, N. Bosnjak, S. and Zrnic, N.: Spatial reduced dynamic model of a bucket wheel excavator with two mats, Lecture Notes in Mechanical Engineering, pp. 215-235, 2019.

[12] Bosnjak, S.M., Arsic, M.A., Gnjatovic, N.B., Milenovic, I.L.J. and Arsic,D.M.: Failure of the bucket wheel excavator buckets, Engineering Failure Analysis, Vol. 64, pp. 247-261, 2018.

[13] Gnjatovic, N., Bosnjak, S. and Stefanovic, A.: The dependency of the dynamic response of a two mast bucket wheel excavator superstructure on the counterweight mass and the degree of Fourier approximation of the digging resistance, Archives of Mining Sciences, Volume 63, pp. 491-509, 2018.

[14] Bosnjak, S.M., Gnjatovic, N.B.: The influence of geometric configuration on response of the bucket wheel excavator superstructure, FME Transactions, Vol. 44, pp. 313-323, 2016.

[15] Incerti, G.: Motion Planning of SCARA Robots for Trajectory Tracking, International Journal of Mechanical and Mechatronics Engineering, Vol. 9, No. 5, pp. 827-836, 2015.

[16] Solazzi, L., Incerti, G. and Petrogalli, C.: Estimation of the dynamic effect in the lifting operations of a boom crane, in: 28th ECMS 2014:309-15.

[17] Tiwari, R., Knowels, J. and Danko,G.: Bucket trajectory classification of mining excavators, Automation in Construction, Vol.31, pp.128-139, 2013.

[18] Salinic,S., Boskovic,G. and Nikolic,M.: Dynamic modelling of hydraulic excavator motion using Kane's equations, Automation in Construction, Vol. 44, pp. 56-62, 2014.
[19] Solazzi, L., Assi, A. and Ceresoli, F.: Excavator arms: Numerical, experimental and new concept design, Composite Structures, Vol. 217, pp.60-74, 2019.

[20] https://meccanica-applicata.unibs.it/

[21] Solazzi, L., Scalmana, R.: New design concept for a lifting platform made of composite material, Applied Composite Materials, Vol.20, pp. 615-626, 2013.

[22] Solazzi, L.: Applied Research for Weight Reduction of an Industrial Trailer, FME Transactions, Vol. 40, pp. 57-62, 2012.

[23] Collotta, M., Solazzi, L.: New design concept of tank made of plastic material for firefighting vehicle, International Journal of Automotive and Mechanical Engineering, Vol. 14, pp.4603-4615, 2017.

[24] Solazzi, L. Assi, A. and Ceresoli, F.: New Design Concept for an Excavator Arms by Using Composite Material, Applied Composite Materials, Vol. 25, No. 3, pp. 601-617, 2017.

[25] Solazzi, L.: Wheel rims for industrial vehicles: Comparative experimental analyses, International Journal of Heavy Vehicle Systems, Vol.18, pp.214225, 2011.

[26] Fantuzzi N., Borgia F.: Theoretical and Applied Insights on Pistons Buckling According to DNV Regulation, Journal of Offshore Mechanics and Arctic Engineering, Vol.141, 2019.

[27] Solazzi, L.: Feasibility study of hydraulic cylinder subject to high pressure made of aluminum alloy and composite material, Composite Structures, Vol. 209, pp. 739-746, 2019.

[28] Solazzi, L., Buffoli, A.: Telescopic Hydraulic Cylinder Made of Composite Material, Applied Composite Materials, in press, 2019.

\section{БАГЕР СА ДВОДЕЛНОМ ИЛИ ТРОДЕЛНОМ СТРЕЛОМ: ИМПЛИКАЦИЈЕ ДИНАМИЧКОГ ПОНАШАҢА И КОНСТРУКЦИЈЕ}

\section{Ф.Ћерезоли}

Циљ рада је да се коришћењем идентичних дијаграма ископавања изврши упоређивање два багера са различитом конфигурацијом стреле, према брзини, убрзању и динамичким перформансама. Испитују се конструкциона решења коришћења дводелне и троделне мобилне стреле. Конструкциону геометрију (дводелна и троделна стрела) багера одређује сврха коришћења. Решење са троделном стрелом се користи у подручјима која онемогућавају велику мобилност багера и где су присутне препреке при ископавању. Динамичко поређење два решења, аналитичко и нумеричко, извршено је у реалним радним условима. Анализа показује да су у условима изравњавања и подизања терета на минималном растојању од осе ротације динамичке перформансе сличне, али да постоји 
значајна разлика у условима подизања на максималном растојању. Разлика такође подразумева значајно варирање сила хидрауличних цилиндара када покрећу терет и стрелу, а што је још више изражено у случају када је стрела израђена од конвенционалних материјала као што су алуминијум и композити. 